\title{
The job diagnostic survey: a functional tool for South African managers
}

\author{
Billy Boonzaier \& Michèle Boonzaier \\ Management School, Cape Technikon, P.O. Box 652, Cape Town 8000. Republic of South Africa
}

Received August 1993, accepted March 1994

\begin{abstract}
Current literature on manpower problems in South Africa has hardly focused on what should be done to improve jobs in order to create job experiences that will fulfil employee goals and organizational goals simultaneously. While the focus has been on the environmental (economic, social, political) and organizational (human resources policies, e.g. affirmative action) components of human resources management, in this article the authors provide guidelines to facilitate a process through which South African managers can practically achieve the optimal fit between current employoes and their jobs. A theory that specifies when workers will display motivation, satisfaction and productive behaviour is reviewed. The accompanying diagnostic instrument is presented with South African norms for use by managers of change. Where remedial action is required, guidelines are proposed to assist managers in planning for an enriched work-place. The authors conclude that this approach represents a powerful strategy that can help organizations achieve their goals as well as meeting the needs of contemporary employees for a more meaningful work experience. This approach ensures that changes in the workplace are brought about on the basis of relevant information regarding the characteristics of jobs and the needs of workers, which is, in turn, based upon fundamental psychological rules and buttressed by South African findings that the theory is empirically sound.
\end{abstract}

\begin{abstract}
Huidige literatuur oor mannekragprobleme in Suid-Afrika het nouliks gefokus op wat gedoen moet word om take te verbeter ten einde werkervarings te skep wat persoonlike doelstellings van die werkers en organisasiedoelstellings tegelykertyd bevredig. Terwyl die klem op die omgewings- (ekonomiese, sosiale, politieke) en organisatoriese (mannekragbestuursbeleid, byvoorbeeld regstellende aksie) komponente van mannekragbestuur was, voorsien die skrywers van hierdie artikel riglyne om die proses te fasiliteer waardcur Suid-Afrikaanse besturders op 'n praktiese wyse die optimale passing tussen huidige werknemers en hul take kan bewerkstellig. ' $n$ Teorie wat spesifiseer wanneer werkers motivering, tevredenheid en produktiewe gedrag sal openbaar, word bestudeer. Die gepaardgaande diagnostiese instrument word voorgestel met Suid-Afrikaanse norme vir gebruik deur bestuurders van verandering. Waar remediërende aksie vereis word, word riglyne voorgestel om bestuurders by te staan in die beplanning van 'n 'verrykte' werkplek. Die skrywers kom tot die gevolgtrekking dat hierdie benadering 'n gesaghebbende strategie is om organisasies te help om hul doelstellings te bereik, sowel as om aan die behoeftes van die hedendaagse werknemer te voldoen, vir ' $n$ meer betekenisvolle werkervaring. Hierdie benadering verseker dat verandering in die werkplek plaasvind op grond van relevante inligting oor die eienskappe van take en die behoeftes van werkers, wat gebaseer is op fundamentele sielkundige beginsels gerugsteun deur Suid-Afrikaanse bevindinge dat die teorie empiries korrek is.
\end{abstract}

\section{Introduction}

Theory and research in the field of management and organizational behaviour have been dominated by a concern for the management of people within organizations. Both organizational productivity and employee alienation from work have become increasingly problematic in South Africa (Gerber, Nel \& Van Dyk, 1992: 44-50). In practice, the concern for the management of people is usually encased in idiosyncratic management practices that are executed with personal conviction. If one, for example, asks a manager how he/she manages so that employees can be both happy and productive, one will most probably receive a theoretically plausible answer, but when one observes what this manager actually does, the discrepancy between what is done and what has been verbalized, is evident.

'It is clear that South Africa has serious problems concerning manpower..., and that these problems will have to be dealt with urgently...' (Gerber, et al., 1992: 50).

One of the new functions which managers must undertake is to seek ways to create job experiences that will fulfil personal employee goals and simultaneously serve organizational purposes. Gerber, et al. view this management responsibility as follows:

'Enterprises must therefore not only recruit, employ, and induct new individuals, but also ensure that they are attached to the enterprise and in particular that they become involved in the pursuit of the goals of the enterprise. Employees will feel attached to or involved with enterprises if factors such as their immediate work environment, job content and so on are satisfactory. This will result in fewer resignations and reduced absentecism with the resultant positive effect on the success of the enterprise' - emphasis added (1992: 154-155).

The intent of this article is to address the question of exactly what should be done by South African managers to improve the worker's experience of working and the productivity performance of the organizational unit involved. The proposed strategy draws on the contribution of management research both locally and internationally (Graham, 1978; Hackman \& Oldham, 1980; Forshaw, 1985; Fried \& Ferris, 1987; Boonzaier, 1989; Champoux, 1991; Griesser, 1993).

The technique behind this strategy provides a set of management tools for diagnosing jobs, a South African norm against which diagnosed jobs can be compared, and a map for translating the diagnostic results into specific action steps for changing the job content and factors in the immediate job environment.

Argyris (in Cunningham, 1991: 18) states: 'Many academic thcories are accused of having a low level of applicability and have little use for solving organizational or social problems'. Cunningham (1991: 18) concludes: 'Managers need theories which are practically useful and relevant'. 
Keeping this in mind, the authors present the following:

1. A theoretical model that enables the manager to understand which conditions in the work-place will get workers 'turned on' to their work.

2. A description of the measuring instrument which the above theoretical model gave rise to and which enables the manager to diagnose the status quo of his or her organizational unit.

3. The results of South African studies which can serve as normative data. This enables managers to compare their diagnoses with norms and identify critical discrepancies.

4. A set of action steps based on the theoretical model and accompanying measuring instrument which enables managers to formulate action plans to address discrepancies.

5. Evidence that this strategy is not merely defensible but a priority in order to address contemporary management issues in the South African work-place.

\section{Theoretical model behind the strategy}

Hackman, Oldham, Janson \& Purdy (in Staw, 1991: 76) equate workers who are prospering in their jobs with a golfer at a driving range. Hitung white balls across green pastures is regarded as meaningful because it provides the opportunity to use and test personal skills and abilities. The golfer knows he is responsible for what happens when he hits the ball, despite the tendency by professionals to claim that a slice was duc to a spectator whispering. Knowledge of the results is direct and immediate as the player sees where the ball goes. These same three psychological states experienced by the golfer are also critical in determining a worker's motivation, satisfaction and performance in the workplace. By experiencing these positive internal feelings when doing well, employees can be both happy and productive. When all three psychological states are high, then internal work motivation, general job satisfaction, growth satisfaction and work quality arc high (refer to Figure 1).

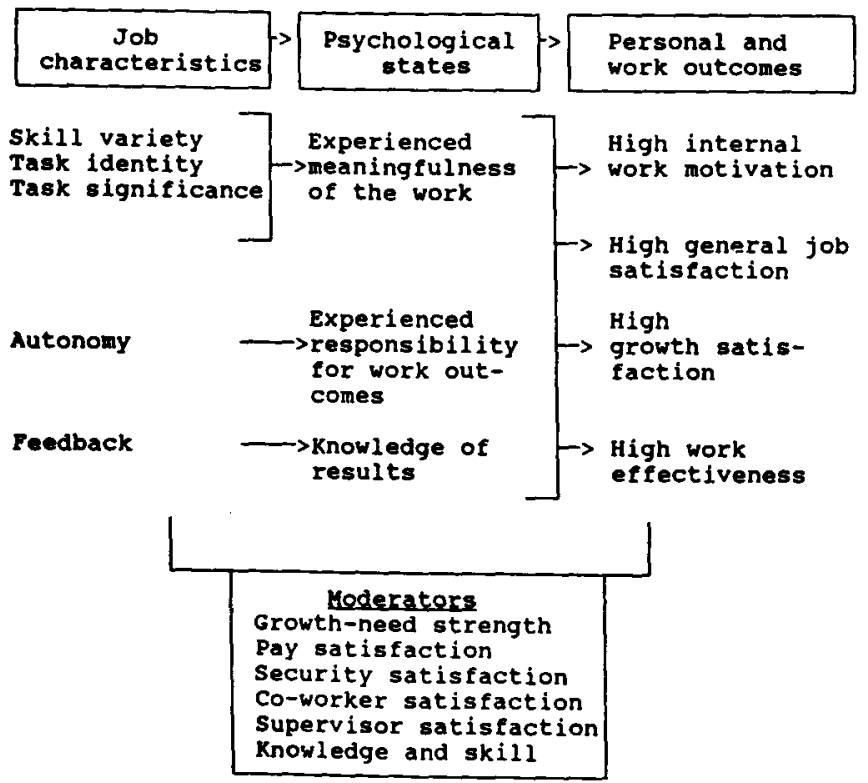

Figure 1 Job characteristics model (Hackman \& Oldham, 1980: 90 )
Hackman \& Oldham (1974: 5-6) describe the various components of the job characteristics model as follows:

\section{Critical psychological states}

- Experienced meaningfulness of the work: the degree to which the employee experiences the job as one which is generally meaningful, valuable and worthwhile.

- Experienced responsibility for work outcomes: the degree to which the employee feels personally accountable and responsible for the results of the work he or she does.

- Knowledge of results: the degree to which the employee knows and understands, on a continuous basis, how effectively he or she is performing the job.

\section{Personal outcomes}

- Internal work motivation: the degree to which the employee is self-motivated to perform effectively on the job, that is, the employee experiences positive internal feelings when working effectively on the job, and negative internal feelings when doing poorly.

- General job satisfaction: an overall measure of the degree to which the employee is satisfied and happy with the job.

- Growth satisfaction: the degree to which an individual is satisfied with opportunities for growth in the job. This particular personal outcome is the result of elaborations on the original model by Hackman, Pearce \& Wolfe (1978: 293).

\section{Work outcomes}

- Work effectiveness: The only work outcome specified by the modcl, namely work effectiveness, is not specifically defined by the theory as this factor is unique to particular work settings.

\section{Job characteristics}

Research by Turner \& Lawrence (1965), Hackman \& Lawler (1971) and Hackman \& Oldham (1974) led to the formulation of five characteristics of the job which enhance the experience of the critical psychological states in the workplace.

Experienced meaningfulness of the work is established by the presence of three job characteristics, namely skill variety, task identity and task significance:

- Skill variety: the degree to which a job requires a variety of different activities in carrying out the work, which involves the use of a number of different skills and talents of the employee.

- Task identity: the degree to which the job requires completion of a 'whole' and identifiable piece of work that is, doing a job from beginning to end with a visible outcome.

- Task significance: the degree to which the job has a substantial impact on the lives or work of other people, whether in the immediate organization or in the external environment.

Autonomy in a job contributes to the worker's experience of responsibility for work outcomes while feedback from the job itsclf contributes to the worker's knowledge of results. 
These two remaining job characteristics can be understood as follows:

- Autonomy: the degree to which the job provides substantial freedom, independence, and discretion by the employee in scheduling the work and in determining the procedures to be used in carrying it out.

- Fcedback from the job itself: the degree to which performing the work activities required by the job results in the employee obtaining direct and clear information about the effectiveness of his or her performance.

The five job characteristics affect the psychological states which in tum influence whether a worker will be satisfied and motivated to perform well. Based on their model, Hackman \& Oldham (1974: 4) compute a score reflecting the overall 'motivating potential' of a job in terms of the five job characteristics. This motivating potential score (MPS) provides a single indicator of the extent to which the five job characteristics are present in a job, which in turn gives rise to motivation, satisfaction and high quality work performance.

\section{Moderators}

Hackman, et al. (in Staw, 1991: 79) state that a job high in motivating potential will not affect everybody in the same manner. That is to say, the relationship between job characteristics and psychological states, as well as the relationship between the psychological states and personal and work outcomes, is mediated by certain moderator variables.

Firstly, workers who have strong needs for personal feelings of accomplishment and growth, and being stimulated and challenged, will respond eagerly to a job high in motivating potential. Workers who have a low growth-need strength may react negatively to change or to jobs high in motivating potential. Growth-need strength (GNS) refers to the strength of the worker's desire to obtain 'growth' satisfactions from his/her work.

Secondly, Oldham, Hackman \& Pearce state that 'employees satisfied with their pay, security, coworkers, and supervisors in the organization should exhibit higher motivation and performance when working in jobs with high motivating potential than individuals dissatisfied with these contextual factors' (1976: 399).

Satisfaction with the context of the job would thus moderate the relationships between the job characteristics, psychological states and the outcome variables. Context satisfaction refers to self-reports of satisfaction with pay, job security, co-workers and supervision.

A final moderator variable in the job characteristics model is a worker's knowledge and skill. For jobs high in motivating potential, incumbents who have sufficient knowledge and skill to perform well, will experience strong positive feelings as a result of their work activities. Workers who are not sufficiently competent will, on the other hand, experience unhappiness and frustration. Knowledge and skill are not specifically defined as they are unique to particular work settings.

The various elements of the job characteristics model as described above thus depict conditions in the work-place which influence the work experience of the employee and which contribute to his motivation and prosperity in the workplace.

\section{From the job characteristics model to management practice}

\section{Job Diagnostic Survey: Introduction}

The Job Diagnostic Survey (JDS) was designed by Hackman \& Oldham (1975) to serve as a management tool for diagnosing jobs and employees' reactions to their jobs. This instrument or questionnaire provides direct measures of the variables in the job characteristics model previously discussed and depicted in Figure 1 (excluding knowledge and skill, and employee work effectiveness).

The JDS also measures two job characteristics that are not included in the job characteristics model, namely:

Table 1 Reliability coefficients of the job characteristics across various studies

\begin{tabular}{|c|c|c|c|c|c|c|c|}
\hline Researchers & $\begin{array}{c}\text { Skill } \\
\text { variety }\end{array}$ & $\begin{array}{c}\text { Task } \\
\text { identity }\end{array}$ & $\begin{array}{l}\text { Task sig- } \\
\text { nificance }\end{array}$ & Autonomy & $\begin{array}{l}\text { Feedback } \\
\text { from job }\end{array}$ & $\begin{array}{l}\text { Feedback } \\
\text { from agents }\end{array}$ & $\begin{array}{l}\text { Dealing with } \\
\text { others }\end{array}$ \\
\hline Bhagat \& Chassie (1980) & 0.68 & 0.78 & 0.72 & 0.66 & 0.73 & - & - \\
\hline Brief \& Aldag (1976) & 0.47 & 0.47 & 0.60 & 0.55 & 0.30 & 一 & - \\
\hline Dunham (1976) & 0.76 & 0.72 & 0.72 & 0.73 & 0.75 & - & - \\
\hline Dunham, Aldag \& Brief (1977) & 0.68 & 0.70 & 0.68 & 0.69 & 0.69 & - & - \\
\hline Evans, Kiggundu \& House (1979) & 0.53 & 0.52 & 0.50 & 0.53 & 0.38 & 0.45 & 0.51 \\
\hline Forshaw (1985) & 0.64 & 0.60 & 0.58 & 0.60 & 0.48 & 0.55 & 0.53 \\
\hline Hackman \& Oldham (1975) & 0.71 & 0.59 & 0.66 & 0.66 & 0.71 & 0.78 & 0.59 \\
\hline Kiggundu (1980) & 0.78 & 0.62 & 0.59 & 0.63 & 0.70 & 0.83 & 0.59 \\
\hline Kim \& Schuler (1979) & 0.80 & 0.69 & 0.73 & 0.67 & 0.73 & 一 & 一 \\
\hline \multicolumn{8}{|l|}{ Oldham, Hackman \& Stepina (in } \\
\hline $\begin{array}{l}\text { Cook, Hepworth, Wall \& Warr, } \\
\text { 1981) }\end{array}$ & 0.68 & 0.61 & 0.58 & 0.64 & 0.68 & 0.75 & 0.62 \\
\hline Pierce \& Dunham $(1978 a, b)$ & 0.74 & 0.70 & - & 0.79 & 0.69 & - & - \\
\hline Schuler, Aldag \& Brief (1977) & 0.68 & 0.55 & - & 0.62 & 0.55 & 0.71 & 0.56 \\
\hline
\end{tabular}


- Feedback from agents: the degree to which the employee receives clear information about his or her performance from supervisors and from co-workers (this dimension is included to provide information to supplement that provided by the 'feedback from job' variable).

- Dealing with others: the degree to which the job requires the employee to work closely with other people, inside and outside the organization, in the execution of work activities.

After the manager has administered and scored the responses of workers, all the JDS variables are depicted on 7 point scales, where 1 represents a low score and 7 a high score. The motivating potential score (MPS) is also computed which ranges from 1 to 343. For a copy of the JDS, refer to Hackman \& Oldham (1980).

Table 2 Reliability coefficients of the psychological states across various studies

\begin{tabular}{lccc}
\hline Researchers & $\begin{array}{l}\text { Expierenced } \\
\text { meaningfulness }\end{array}$ & $\begin{array}{c}\text { Expierenced } \\
\text { responsibility }\end{array}$ & $\begin{array}{l}\text { Knowledge } \\
\text { of results }\end{array}$ \\
\hline Forshaw (1985) & 0.69 & 0.71 & 0.74 \\
$\begin{array}{l}\text { Hackman \& Oldham (1975) } \\
\begin{array}{l}\text { Oldham, et al. (in Cook, } \\
\text { et al., 1981) }\end{array}\end{array}$ & 0.74 & 0.72 & 0.76 \\
\hline
\end{tabular}

Table 3 Reliability coefficients of the personal outcomes across various studies

\begin{tabular}{lccc}
\hline Researchers & $\begin{array}{c}\text { Internal } \\
\text { motivation }\end{array}$ & $\begin{array}{c}\text { General job } \\
\text { satisfaction }\end{array}$ & $\begin{array}{c}\text { Growth satis- } \\
\text { faction }\end{array}$ \\
\hline $\begin{array}{l}\text { Forshaw (1985) } \\
\text { Hackman \& Oldham }\end{array}$ & 0.68 & 0.74 & 0.70 \\
$\begin{array}{l}\text { (1975) } \\
\begin{array}{l}\text { Oldham, et al. (in } \\
\text { Cook, et al., 1981) } \\
\text { Warr, Cook \& Wall }\end{array}\end{array}$ & 0.76 & 0.76 & 0.84 \\
\begin{tabular}{l}
$(1979)$ \\
\hline
\end{tabular} & 0.82 & 0.77 & 0.84 \\
\hline
\end{tabular}

Empirical properties of the Job Diagnostic Survey

Leibold (1992) stresses the importance of applying and utilizing valid and reliable theories and management tools in South Africa today.

Boonzaier (1989: 96-104) provides a summary of studies which shows the internal consistency reliability for all the scales of the JDS (refer to Tables 1 to 4). Most studies report satisfactory intemal consistency reliability for JDS scales when compared with Nunnally's (1967) standard of 0.5 to 0.6 .

Hackman \& Oldham, in developing the JDS, report internal consistency reliability coefficients as well as discriminant validity coefficients (the latter by computing median off-diagonal correlations) and conclude as follows:

'In general, the results suggest that both the internal consistency reliability of the scales and the discriminant validity of the items are satisfactory' (1975: 164).

The validity of the job characteristics model was assessed by Fried \& Ferris (1987) by conducting a comprehensive review of nearly 200 relevant studies on the model as well as by applying meta-analytic procedures on relevant correlational data from 76 research studies. The evidence indicated that the available correlational results are reasonably valid and thus support the model. A recent study by Champoux (1991) also confirms the validity of the job characteristics model.

\section{Normative data of South African studies}

The JDS was administered by the authors to more than 6000 employees in 130 job categories ranging from semi-skilled to highly-skilled managerial and professional workers. A subset of this data was used in establishing a comprehensive South African norm as reported in Table 5.

The results of carlier South African studies by Graham (1978) and Forshaw (1985) regarding the JDS are also reported. For comparative purposes Table 5 includes the American national norm.

The South African norms in Table 5 provide the manager with a standard for use in interpreting JDS scores. The South African manager can use this diagnostic tool (JDS) to

Table 4 Reliability coefficients of the moderator variables across various studies

\begin{tabular}{lcccccc}
\hline Researchers & $\begin{array}{c}\text { Security } \\
\text { satisfaction }\end{array}$ & $\begin{array}{c}\text { Salary } \\
\text { satisfaction }\end{array}$ & $\begin{array}{c}\text { Co-worker } \\
\text { satisfaction }\end{array}$ & $\begin{array}{c}\text { Supervisor } \\
\text { satisfaction }\end{array}$ & $\begin{array}{c}\text { Growth-need } \\
\text { strength A }\end{array}$ & $\begin{array}{c}\text { Growth-need } \\
\text { strength B }\end{array}$ \\
\hline Evans, et al. (1979) & - & - & - & - & - & 0.60 \\
Forshaw (1985) & 0.74 & 0.77 & 0.60 & 0.68 & - & 0.56 \\
$\begin{array}{l}\text { Ganster (1980) } \\
\text { Hackman \& Oldham (1975) }\end{array}$ & - & - & - & - & - & 0.73 \\
Oldham, et al. (1976) & - & - & - & - & - & 0.71 \\
$\begin{array}{l}\text { Oldham, et al. (in Cock, et al., } \\
\text { 1978) }\end{array}$ & 0.73 & 0.86 & 0.64 & 0.87 & 0.87 & 0.71 \\
$\begin{array}{l}\text { Pierce, Dunham \& Blackbum } \\
\text { (1979) }\end{array}$ & - & - & - & - & 0.86 & - \\
Rousseau (1978) & - & - & - & - & 0.85 & - \\
Sione, Ganster, Woodman \& & & - & - & - & 0.85 & 0.67 \\
Fusilier (1979) & - & - & - & & & \\
\hline
\end{tabular}


Table 5 Job Diagnostic Survey norms

\begin{tabular}{|c|c|c|c|c|c|c|c|c|}
\hline \multirow{3}{*}{ Variables } & \multicolumn{8}{|c|}{ Researchers* } \\
\hline & \multicolumn{2}{|c|}{$1^{*}$} & \multicolumn{2}{|l|}{$2 *$} & \multicolumn{2}{|c|}{ 3* } & \multicolumn{2}{|l|}{$4^{*}$} \\
\hline & $x$ & (S) & $x$ & (S) & $x$ & (S) & \& & (S) \\
\hline \multicolumn{9}{|l|}{ Job characteristics } \\
\hline Skill variety & 4.3 & $(1.6)$ & 4.7 & (1.6) & 3.7 & (1.1) & 4.4 & (1.4) \\
\hline Task identity & 4.5 & $(1.3)$ & 4.7 & (1.4) & 5.1 & (1.1) & 4.7 & (1.3) \\
\hline Task significance & 5.4 & (1.4) & 5.5 & (1.3) & 4.9 & (1.2) & 5.3 & (1.3) \\
\hline Autonomy & 4.6 & $(1.5)$ & 4.9 & (1.4) & 4.1 & $(1.2)$ & 4.7 & (1.3) \\
\hline Feedback from job & 4.7 & (1.3) & 4.9 & (1.3) & 5.1 & $(1.1)$ & 5.0 & (1.3) \\
\hline Feedback from agents & 4.3 & (1.3) & 4.1 & - & 4.2 & $(1.4)$ & 4.0 & (1.5) \\
\hline Dealing with others & 5.4 & (1.2) & 5.6 & - & - & - & 5.4 & (1.2) \\
\hline \multicolumn{9}{|l|}{ Psychological states } \\
\hline Experienced meaningfulness & 5.2 & (1.3) & 5.2 & (1.1) & 4.8 & $(0.9)$ & 6.0 & 一 \\
\hline Experienced responsibility & 4.8 & (1.1) & 5.5 & $(1.0)$ & 5.1 & $(0.8)$ & 5.8 & - \\
\hline Knowledge of results & 4.7 & (1.3) & 5.0 & $(1.1)$ & 4.9 & $(1.0)$ & 5.0 & - \\
\hline \multicolumn{9}{|l|}{ Personal outcomes } \\
\hline Internal work motivation & 5.2 & $(1.0)$ & 5.6 & - & 5.2 & $(0.7)$ & 5.7 & 一 \\
\hline General satisfaction & 4.7 & (1.4) & 4.7 & - & 4.4 & $(1.1)$ & 5.6 & - \\
\hline Growth satisfaction & 5.0 & $(1.5)$ & 4.8 & - & 4.5 & $(1.2)$ & 5.5 & 一 \\
\hline \multicolumn{9}{|l|}{ Moderators } \\
\hline Job security satisfaction & 5.2 & (1.4) & 4.9 & - & Comt & ined & 5.5 & - \\
\hline Pay satisfaction & 4.2 & $(1.7)$ & 4.3 & - & Score & & 5.0 & - \\
\hline Co-worker satisfaction & 5.4 & $(1.0)$ & 5.4 & - & & & 5.7 & - \\
\hline Supervisor satisfaction & 4.9 & $(1.5)$ & 4.9 & - & 4.9 & $(0.7)$ & 5.8 & - \\
\hline Growth-need strength $A$ & 5.7 & (1.4) & - & - & - & - & 5.3 & (median) \\
\hline Growth-need strength B & 3.2 & $(0.5)$ & - & - & 3.1 & $(0.8)$ & 3.1 & (median \\
\hline Growth-need (combined) & - & - & 5.0 & - & \multicolumn{2}{|c|}{-} & \multicolumn{2}{|c|}{ - } \\
\hline Motivation Potential Score (MPS) & \multicolumn{2}{|c|}{114} & \multicolumn{2}{|l|}{128} & 98 & & \multicolumn{2}{|c|}{122} \\
\hline Subjects & \multicolumn{2}{|c|}{4012} & \multicolumn{2}{|l|}{6930} & \multicolumn{2}{|c|}{135} & 269 & \\
\hline
\end{tabular}

\section{*Researcher 1:}

Boonzaier (1989): This sample of 4012 represents $89 \%$ of the total work force at a community service organization with 46 organizational units spread throughout the Republic of South Africa and Namibia. The subjects represent 93 different occupations ranging from semi-skilled to highly-skilled managerial and professional workers.

*Researcher 2:

Oldham, Hackman \& Stepina (in Hackman \& Oldham, 1980): These American norms are based on the responses of 6930 employees representing 876 different jobs in 56 organizations. Some standard deviations are reported by Fried \& Ferris (1987).

*Researcher 3:

Forshaw (1985): These figures were compiled from the responses of 135 non-supervisory clerical insurance personnel at a Cape Town-based company. The data represents 33 different jobs and qualifications range from standard 8 to 10.

*Researcher 4:

Graham (1978): This study was conducted at 27 Westem Cape organizations. A sample of $269 \mathrm{em}-$ ployees was selected in such a manner to ensure realistic comparisons between high versus low qualified workers, old versus young workers, male versus female workers, strong versus weak growth-need strength workers, managerial versus non-managerial workers as well as workers with a rural upbringing versus those with an urban background.

Note: The South African norms of Researcher 1 were computed by calculating the mean score for the subjects according to the variables. The American norm was computed by averaging the scores of employees who work on each of the 876 jobs and then computing overall means across those jobs. 
evaluate the jobs in his/her organizational unit and employees' reactions to their jobs by pinpointing the aspects of specific jobs which deviate from the given norms and which require management action.

\section{Management practice to facilitate change}

The following paragraphs outline the steps to be followed by managers when diagnosing jobs prior to changing them, and focuses on how diagnostic conclusions can be translated into specific job enrichment strategies.

Based on the framework of Hackman, et al. (in Staw, 1991: 81) the following steps are proposed for managers to follow and the corresponding questions which they must answer when diagnosing work systems:

Step 1: Are motivation and satisfaction central to the problem? The manager must examine the scores of employees within a specific department or job category on the motivation and satisfaction scores of the diagnostic instrument. For those departments/job categories where motivation and satisfaction are problematic when compared to the South African norm, the manager would continue to step 2.

Step 2: Is the job low in motivating potential? The manager would examine the motivating potential score of the target job and compare it to the motivating potential score of other jobs and the South African norm to determine if the characteristics of the target job are a probable cause of the motivation and satisfaction problems. If the MPS is low, the manager would continue to step 3; if not, attention should be given to other possible reasons in the immediate work environment, for example dissatisfaction with pay, job security, co-workers and supervision (the moderator variables).

Step 3: What specific aspects of the job are causing the problem? This involves examining the target job with respect to each of the job characteristics to identify the specific strengths and weaknesses of the job and then compiling a profile which would illustrate the main causes of problems compared to the South African norm. Step 4 now becomes the focus.

Step 4: Are the employees ready for change? The manager would examine the growth-need strength of employces in the target job according to the JDS. This measure can be helpful in planning how to introduce workers to changes in their jobs, e.g. cautiously or not, since employees high on growth-needs usually respond more readily to job enrichment than do employees with little need for growth.

Diagnostic conclusions should next be formulated and attention be given to the planning of specific action steps for introducing change. The profile and diagnostic conclusions indicate which job characteristics need remedial attention. The manager can use the following implementing concepts as a guideline in formulating a specific change strategy for certain problem target jobs. Each one of the following implementing concepts enriches the characteristics of a job as indicated in Figure 2:

1. Combining tasks: Both the skill variety and the task identity of a job can be increased by putting together existing, fractionalized tasks to form new and larger modules of work. When tasks are combined, the various tasks required to complete a given piece of work are
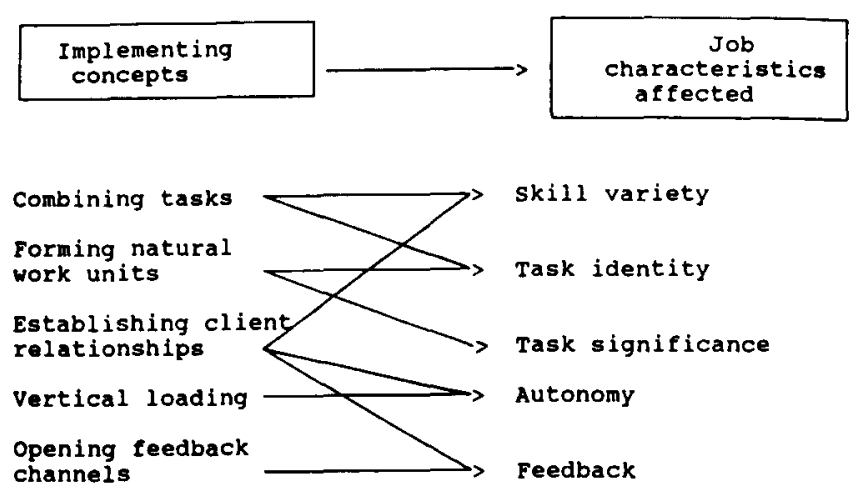

Figure 2 Relationship between the implementing concepts and the job characteristics (Hackman, et al., in Staw, 1991: 83)

performed by one person, rather than by a few individuals who do separate, smaller parts of a job. The job thus requires the application of a wider variety of skills and the worker identifies more strongly with a meaningful whole task.

2. Forming natural work units: When work is divided into natural work units, the various basic tasks given to workers are grouped into different meaningful categories. Ownership of a category or natural work unit is established and a specific worker thus accepts continuing responsibility for that unit. Even workloads need to be assigned. Under this arrangement, employees would experience their tasks as a meaningful whole (task identity) and workers tend to develop a growing sense of how the completion of a natural work unit affects other people (task significance).

3. Establishing client relationships: Natural work units can often be formed around specific groups of clients of the work. It may be possible to put an employee in direct contact with those clients and give him or her continuing responsibility for managing relationships with them. Crcating client relationships is a three-step process. First, the client must be identified. Second, the most direct contact possible between the worker and the client must be established. Third, criteria must be set up by which the client can judge the quality of the product or service he/she receives. The client should have a means of rclaying his judgements directly back to the worker. Contact between worker and client should be as close as possible - face-to-face contact is highly desirable - and as frequent as necessary.

By enabling employees to establish direct relationships with the clients of their work, skill variety increases because of the need to exercise interpersonal skills in maintaining the client relationship as well as skills in completing the task itself.

Autonomy increases because individuals have personal responsibility for deciding how to manage their relationships with the clients. Feedback increases because of additional opportunities for workers to obtain direct and immediate praise or criticism of their work outputs from the persons who receive the work.

4. Vertical loading: When a job is vertically loaded, autonomy increases. Workers are given increased control 
over the work as a result of managers delegating responsibility and authority that formerly were reserved for higher levels of management.

There are several ways to vertically load a job. Jobholders can be given discretion in setting schedules, determining work methods, and deciding when and how to check on the quality of the work produced. Employees can make their own decisions about when to start and stop work, when to take breaks, and how to assign priorities. Workers can also benefit from knowing something about the costs of their jobs and the potential effect upon profit. They should be encouraged to seck solutions to problems on their own, rather than always relying on the manager. The net effect of such changes should be an increase in workers' fcelings of personal responsibility for their work and, ultimately, an improvement in their personal and work outcomes.

5. Opening feedback channels: In virtually all jobs there are ways to open channels of feedback to employees to help them leam whether their performance is improving, deteriorating, or remaining at a constant lcvel. It is better for a worker to receive fecdback about his performance from the job itself, as it is more immediate and private than manager-supplied feedback. It increases the workers's feelings of personal control over the work and avoids many of the potentially disruptive interpersonal problems that can develop through feedback from the manager.

This change simply involves removing existing blocks that isolate the worker from naturally occuring data about performance. This includes establishing direct client relationships and making the worker responsible for quality checks rather than external individuals. Quality control must be placed close to the worker so that the worker does not regard it as someone else's concem. Performance records must not only be transmitted up in the organization, but fcedback must be given to workers in order that they know how well they are performing and what possible improvements they need to make. As workers gain more knowledge of results, employec motivation, satisfaction and productivity should increase.

With the aid of the above model and norms, South African managers can thus diagnose jobs in a specific organizational unit and introduce changes where remedial action is required. By utilizing the above-mentioned guidelines, managers can formulate action plans for change unique to the specific organizational circumstances which they are faced with.

\section{Evidence of the validity and necessity of the pro- posed strategy in South Africa}

The questions posed by management practitioners and researchers alike are, firstly, whether the job characteristics model is functional within the South African business environment, secondly, whether the proposed strategies lead to measurable improvements when introduced in organizations, and thirdly, whether the current manpower scenario in South Africa warrants the proposed interventions.
Addressing the first concern, namely the applicability of the theoretical model and the accompanynig JDS instrument in South African business practice, the authors gathered data on 4012 employees of a community service organization stationed at 46 organizational units throughout South Africa and Namibia. This data was used to test the validity of the job characteristics model in South Africa, more specifically, the relationship between job characteristics and motivation and satisfaction on the job.

Processing of the results show a significant correlation between the motivating potential score (MPS) and general job satisfaction, growth satisfaction, and internal motivation (refer to Table 6). The MPS represents the extent to which the five job characteristics are present in a job.

This result indicates that people who work in jobs with high scores on the job characteristics (and hence a high MPS) are more satisfied and motivated than people who work in jobs low on the job characteristics.

These South African findings coincide with the job characteristics model as formulated by Hackman \& Oldham (1980). The job characteristics theory and accompanying JDS are thus suitable for use in South Africa.

Addressing the second concem, namely whether implementation of the proposed strategies actually results in measurable improvements, the authors report that, although they have been involved in administering the JDS and implementing the enrichment principles in organizational change projects within the South African context, they are not aware of any empirical research dealing specifically with the measured success of job enrichment on personal and work outcomes within South African organizations.

Hackman, et al. (in Staw, 1991: 90-91), however, in a promising study of 196 workers from an insurance business environment, report dramatic gains resulting from the introduction of the implementing concepts in order to enrich the characteristics of jobs. Table 7 represents a tabulation of the results reported in Staw (1991).

Findings clearly show marked improvements in both personal and job outcomes when the proposed change strategies are introduced into an organization.

Addressing the final concem, namely the necessity of the proposed strategies within the South African work-place, attention needs to be focused on contemporary manpower

Table 6 Partial correlation coefficients between motivating potential score (MPS) and personal outcomes

MPS

\begin{tabular}{ll}
\hline Personal outcomes & \\
General satisfaction & $0.48^{*}$ \\
Growth satisfaction & $0.58^{*}$ \\
Intemal motivation & $0.41^{*}$ \\
\hline$p<0.001$ & \\
\hline
\end{tabular}


Table 7 Results ${ }^{\text {ab }}$ of job enrichment intervention at The Travelers Insurance Companies

\begin{tabular}{lcc}
\hline Dimension & $\begin{array}{c}\text { Experimental } \\
\text { group } \\
(n=98)\end{array}$ & $\begin{array}{c}\text { Control } \\
\text { group } \\
(n=98)\end{array}$ \\
\hline Job outcomes & & \\
1. Quantity of work (productivity index) & $+39.60 \%$ & $+8.10 \%$ \\
2. Quality of work (error rates) & $-0.54 \%$ & - \\
3. Absenteeism & $-24.10 \%$ & $+29.00 \%$ \\
Personal outcomes & & \\
1. General job satisfaction & $+16.50 \%$ & $+0.50 \%$ \\
\hline
\end{tabular}

- Positive $(+)$ indicates increase; negative $(-)$ indicates decrease

b Significance levels not reponted

Source: adapted from Hackman, et al. (in Staw, 1991)

problems in South Africa, which include low labour productivity, labour unrest and strikes, absenteeism and labour turnover, amongst others. These problems are, in part, due to job alienation and worker dissatisfaction with their quality of work life, including lack of recognition, uninteresting work, poor relationships with colleagues, isolation because of working on their own, and a lack of meaningfulness because employees experience no sense of fulfilment from the goods they produce or from the services they render (Gerber, et al., 1992: 44-47;350-351). The accuracy of the job characteristics model in addressing specifically these manpower problems, and the empirical properties of the accompanynig JDS, make the proposed strategies a most appropriate framework on which to base current management interventions.

\section{Conclusion}

This article examined a basic theory of how managers in South Africa can create job experiences for workers that will fulfil personal employee goals and simultaneously serve the goals of the organization. The theory proposed a set of job characteristics that create the conditions for internal work motivation, productive performance as well as satisfaction to develop. A set of action steps are recommended for incorporation in a change strategy to enhance these job characteristics.

The job characteristics model itself is shown as applicable in South African organizations and the Job Diagnostic Survey, with accompanying South African norms, satisfies the basic requirements of reliability and validity for utilization in South Africa by management scientists and practitioners alike.

\section{References}

Bhagat, R.S. \& Chassie, M.B. 1980. 'Effects of changes in job characteristics on some theory-specific attitudinal outcomes: Results from a naturally occuring quasi-experiment', Iluman Relations, Vol. 33: 297-313.

Boonzaier, W. 1989. ' $n$ Evaluering van die taakeienskappe model in die S.A. Vloot. Masters thesis. Bellville: University of Western Cape.
Brief, A.P. \& Aldag, RJ. 1976. 'Correlates of role indices'. Journal of Applied Psychology, Vol. 61: 468-472.

Champoux, J.E. 1991. 'A multivariate test of the job characteristics theory of work motivation', Journal of Organizational Behaviour, Vol. 12: 431-446.

Cook, J.D., Hepworth, S.J., Wall, T.D. \& Warr, P.B. 1981. The experience of work. London: Academic Press.

Cunningham, J.B. 1991. 'Using "Paperback" and academic theories for practice', Management Decision, Vol. 29, No. 7: 18-23.

Dunham, R.B. 1976. 'The measurement and dimensionality of job characteristics', Journal of Applied Psychology. Vol. 61: $404-409$.

Dunham, R.B., Aldag, R.J. \& Brief, A.P. 1977. 'Dimensionality of task design as measured by the Job Diagnostic Survey'. Academy of Management Journal, Vol. 20: 209-223.

Evans, M.G., Kiggundu, M.N. \& House, RJ. 1979. 'A partial test and extension of the job characteristics model of motivation', Organizational Behaviour and Human Performance, Vol. 24: 354-381.

Forshaw, K.L. 1985. Growth need strength as a moderator variable in job design. Masters thesis. Cape Town: University of Cape Town.

Fried, Y. \& Ferris, G.R. 1987. 'The validity of the job characteristics model: a review and meta-analysis', Personnel Psycho. logy, Vol. 40: 287-322.

Ganster, D.C. 1980. 'Individual differences and task design: a laboratory experiment'. Organizational Behaviour and Human Performance, Vol. 26: 131-148.

Gerber, P.D., Nel, P.S. \& Van Dyk, P.S. 1992. Human resources management. Second edition. Halfway House: Southem Book Publishers.

Graham, A. 1978. Die invloed van sekere taak- en individuele eienskappe op werkgedrag. Masters thesis. Stellenbosch: University of Stellenbosch.

Griesser, J.W. 1993. 'Motivation and information system professionals', Journal of Managerial Psychology, Vol. 8: 21-30.

Hackman, J.R. \& Lawler, E.E. 1971. 'Employee reactions to job characieristics', Journal of Applied Psychology, Vol. 55: 259-286.

Hackman, J.R. \& Oldham, G.R. 1974. The Job Diagnostic Survey: an instrument for diagnosing the motivational polential of jobs. Technical Report no. 4, Department of Administrative Sciences, Yale University.

Hackman, J.R. \& Oldham, G.R. 1975. 'Development of the Job Diagnostic Survey'. Journal of Applied Psychology, Vol. 60. No. 2: $159-170$.

Hackman, J.R. \& Oldham, G.R. 1980. Work redesign. Massachusetts: Addison-Wesley.

Hackman, J.R., Pearce, J.L. \& Wolfe, J.C. 1978. 'Effects of changes in job characteristics on work attitudes and behaviour', Organizalional Behaviour and Human Performance, Vol. 21: 289-304.

Kiggundo, M.N. 1980. 'An empirical test of the theory of job design using multiple job ratings', Human Relations, Vol. 33: 339-351.

Kim, J.S. \& Schuler, R.S. 1979. 'The nature of the task as a moderator of the relationship between extrinsic feedback and employee responses', Academy of Management Journal, Vol. 22: $157-162$.

Leibold, M. 1992. Address at Business Economics Symposium. Cape Town: Cape Technikon.

Nunnally, J.C. 1967. Psychometric theory. New York: McGrawHill. 
Oldham, G.R., Hackman, J.R. \& Pearce, J.L. 1976. 'Conditions under which employees respond positively to enriched work', Journal of Applied Psychology, Vol. 61: 395-403.

Pierce, J.L. \& Dunham, R.B. 1978a. 'The measurements of perceived job characteristics: The Job Diagnostic Survey versus the Job Characteristic Inventory', Academy of Management Journal, Vol. 21: 123-128.

Pierce, J.L. \& Dunham, R.B. 1978b. 'An empirical demonstration of the convergence of common macro- and micro-organization measures', Academy of Management Journal, Vol. 21: $410-418$.

Pierce, J.L., Dunham, R.B. \& Blackburn, R.S. 1979. 'Social systems structure, job design and growth need strength: a test of a congruency model', Academy of Management Journal, Vol. 22: 223-240.

Rousseau, D.M. 1978. 'Characteristics of departments, positions and individuals: contexts for attitudes and behaviour', Administrative Science Quarterly, Vol. 23: 521-540.

Schuler, R.S., Aldag. RJ. \& Brief, A.P. 1977. 'Role conflict and ambiguity: a scale analysis', Organizational Behaviour and Human Performance, Vol. 20: 111-128.

Staw, B.M. (Ed.). 1991. Psychological dimensions of organizational behaviour. New York: Macmillan Publishing Company.

Stone, E.F., Ganster, D.C., Woodman, R.W. \& Fusilier, M.R. 1979. 'Relationships between growth need strength and selected individual differences measures employed in job design research', Journal of Vocational Behaviour, Vol. 14: 329-340.

Turner, A.N. \& Lawrence, P.R. 1965. Industrial job and the worker. Boston: Harvard University Press.

Warr, P.B., Cook, J. \& Wall, T.D. 1979. 'Scales for the measurement of some work attitudes and aspects of psychological well-being', Journal of Occupational Psychology. Vol. 52: 129-148. 